\title{
Determination of total petroleum hydrocarbons in soil from different locations using infrared spectrophotometry and gas chromatography
}

\author{
Paula Paíga, Lurdes Mendes, José T. Albergaria, Cristina M.Delerue-Matos
}

\begin{abstract}
Total petroleum hydrocarbons (TPH) are important environmental contaminants which are toxic to human and environmental receptors. Several analytical methods have been used to quantify TPH levels in contaminated soils, specifically through infrared spectrometry (IR) and gas chromatogra- phy (GC). Despite being two of the most used techniques, some issues remain that have been inadequately studied: a) applicability of both techniques to soils contaminated with two distinct types of fuel (petrol and diesel), b) influence of the soil natural organic matter content on the results achieved by various analytical methods, and c) evaluation of the performance of both techniques in analyses of soils with different levels of contamination (presumably non-contaminated and po- tentially contaminated). The main objectives of this work were to answer these questions and to provide more complete information about the potentials and limitations of GC and IR techniques. The results led us to the following conclusions: a) IR analysis of soils contaminated with petrol is not suitable due to volatilisation losses, b) there is a significant influence of organic matter in IR analysis, and c) both techniques demonstrated the capacity to accurately quantify TPH in soils, irrespective of their contamination levels.
\end{abstract}

\section{Keywords}

Total petroleum hydrocarbons, soil, infrared spectrophotometry, gas chromatography

Introduction

Soils contaminated with petroleum products create widespread environmental problems due to their ad- verse effects (Wang et al., 1999). It is becoming urgent to assess contamination in some sites in question, to remediate and monitor these cleaning processes and to evaluate final quality of the soil.

TPH are an important group of environmental contaminants that are toxic to human and environmental receptors (Park \& Park, 2011). In 1999 the United States Environmental Protection Agency (USEPA)Site Program began its evaluation of field methods for the determination of TPH in soils. This was an ambitious project that involved the establishment of a TPH definition and the development of a reference method for its quantification. One of the methods se- lected for this evaluation was SW-846 Method 9074 (Lynn et al., 2002; USEPA, 1996a).

At present, a wide variety of specific and non- specific methods are used for analysis of TPH. The conventional nonspecific methods include: i) field- screening gas chromatography with flame ionisation (GC-FID) or photoionisation detection (GC-PID) (API, 1992, 1994; USEPA, 1996b), ii) gravimetric determination and infrared spectrophotometry (IR), such as USEPA methods 418.1, 8440, and $9071 \mathrm{~B}$, and American Society for Testing and Materials (ASTM)methods 3414 and 3921 (USEPA, 1978, 1996c, 1998; ASTM, 1997a, 1997b), iii) turbidimetry (USEPA, 1996a), iv) ultraviolet and fluorescence spectroscopy (Burns, 1993; ASTM 1997c), v) thin-layer chromatog- 
raphy (TLC) (which has been extensively used in the component class characterisation of various oils and respective fractions) (Wang et al., 2010), vi) high per- formance liquid chromatography (HPLC) (Krahn et al., 1993), vii) sizeexclusion chromatography (Krahn

\& Stein, 1998), viii) supercritical fluid chromatogra- phy (SFC) (ASTM, 1997d), ix) total organic carbon(Schreier et al., 1999), $\mathrm{x}$ ) isotope ratio mass spectrom- etry (Wang et al., 1999), and xi) fibre optic IR sensor for identification of various petroleum samples (Ge et al., 1995). The non-specific techniques have been used to screen TPH and petroleum saturated and aromatic compounds in sediments, to assess site contamination, to identify and quantify petroleum products that may exist in soil or water, and to qualitatively analyse and compare oil degradation due to weathering (Wang et al., 1999).

Fingerprint analysis has been developed using specific and advanced techniques such as: i) gas chromatography-mass spectrometry (GC-MS),

ii) high performance liquid chromatography-mass spectrometry (HPLC-MS), iii) isotope dilution mass spectrometry (IDMS), iv) nuclear magnetic resonance (NMR), and v) electrospray ionisation-mass spec- trometry (ESI-MS) (Wang \& Fingas, 1997, 2003; Eide

\& Zahlsen, 2005; Daling et al., 2002). Many USEPA and ASTM methods have been modified to improve selectivity and sensitivity for measuring spilled oil and petroleum products in soils and water (ASTM, 1997a, 1997b, 1997e, 1997f, 1997g; Sink \& Hardy, 1994).

Wright (1995) reported that using field measure- ment methods instead of laboratory analyses it was possible to analyse more soil samples, faster and at lower cost. Lambert et al. (2001) used two test kits for soil analyses: the immunoassay-based EnviroG- ard petroleum fuel in soil test kit and a colorimet- ric test procedure (DR/2000). Lynn et al. (2002) analysed performance of the PetroFLAG hydrocarbon analyser system (commercial version of SW- 846 Method 90747). Using co-elution in a single-step chromatographic separation, it is impossible to iden- tify and quantify the target compounds. Combined methods such as: HPLC-GC, GC-GC, GC $\times$ GC (two- dimensional GC), or supercritical fluid chromatogra- phy (SFC) are commonly used to improve the quality of analysis. Pál et al. (1998) used SFC-GC/MS for de- tailed analysis of different hydrocarbon groups in the range of petroleum fractions and Mao et al. (2009) estimated eco-toxicity of petroleum hydrocarbon mixtures in soil using HPLC-GC $\times$ GC. All these analytical methods have been modified in order to eliminate ma- trix interferences, reduce the amount of solvent used, find alternative and less toxic solvents, simplify ana- lytical procedures amongst other requirements.

Methods of GC and IR techniques are commonly used to determine levels of TPH in contaminated soils; however, some issues remain that have not been suffi- ciently studied. These issues are studied in this work and focus on: a) applicability of both techniques to the analysis of soils contaminated with two distinct types of fuel (petrol and diesel), b) influence of soil natural organic matter on TPH determination, and c) eval- uation of the performance of both techniques on the analysis of soils with different levels of contamination (presumably non-contaminated and potentially con- taminated). The work sought to provide a response to these questions and to supply more complete informa- tion on the potentials and limitations of GC and IR techniques applied to TPH determination.

\section{Experimental}

\section{Materials and methods}

The ASTM D5307 (ASTM, 1997h) Crude oil quan- titative STD analytical standard was obtained from Supelco (Bellefonte, PA, USA), and diesel and petrol were acquired from a Portuguese oil refinery (Petrogal, S.A., Porto). Isooctane, pentane, potassium dichro-mate, and ortho-phosphoric acid of 85 mass \% were obtained from Merck (Darmstadt, Germany), 1,1,2-trichloro-1,2,2-trifluoroethane and hexadecane were obtained from Sigma-Aldrich (Bellefonte, PA, USA). Sodium sulphate, ammonium iron(II) sulphate hex- ahydrate, and benzene were obtained from Riedel- de Häen (Seelze, Germany), and sulphuric acid 95-97 mass \% was obtained from Fluka (Bellefonte, PA, USA). All reagents were of analytical grade or higher purity.

Deionised water $\left(15.0 \mathrm{M} \Omega \mathrm{cm}^{-1}\right)$ was produced us- ing an Elix3 Advantage system (Millipore, Molsheim, France). High-purity grade silica gel (Davisil Grade 635), pore size: $60 \AA$ A $60-100$ mesh was purchased from Sigma-Aldrich (Bellefonte, PA, USA).

Following the EPA Method 8440 (USEPA, 1996c), the standard solution for IR was prepared by mix- ing hexadecane, isooctane, and benzene as the "ref- erence oil" in a $50-\mathrm{mL}$ glass-stoppered bottle. The integrity of the mixture was maintained by keeping the bottle duly stoppered except when withdrawing aliquots. The stock solution was prepared by dilut- ing the reference oil 200-fold with 1,1,2-trichloro-1,2,2trifluoroethane. A stock solution for GC determina- tion was prepared by a 100 -fold dilution of diesel with pentane. Working standards were prepared by accurate dilution of the stock solutions using 1,1,2- trichloro-1,2,2-trifluoroethane for IR and pentane for GC-FID on the day of use. All solutions were stored at $4{ }^{\circ} \mathrm{C}$. The ASTM D5307 reference oil was prepared in 1,1,2-trichloro-1,2,2-trifluoroethane for IR determination and in pentane for GC analysis.

For determination of the organic matter content, three solutions were prepared: a) $0.40 \mathrm{~mol} \mathrm{~L}^{-1}$ am- monium iron(II) sulphate hexahydrate (SFA) in $0.40 \mathrm{~mol} \mathrm{~L}^{-1}$ sulphuric acid; ii) oxidant mixture of $0.068 \mathrm{~mol} \mathrm{~L}^{-1}$ potassium dichromate in $7.50 \mathrm{~mol} \mathrm{~L}^{-1}$ sul- 
phuric acid and $3.85 \mathrm{~mol} \mathrm{~L}^{-1}$ ortho-phosphoric acid, and iii) potassium dichromate $0.033 \mathrm{~mol} \mathrm{~L}^{-1}$ in de- ionised water.

An IR Spectrolab Interspec 200X, Fourier trans- form infrared spectrometer (FTIR, Garforth, Leeds,UK) and a quartz cell with a $30-\mathrm{mL}$ capacity and a $10-\mathrm{cm}$ light path (for TPH concentration range from $0.5 \mathrm{mg} \mathrm{L}^{-1}$ to $50 \mathrm{mg} \mathrm{L}^{-1}$ ) were used.

GC-FID analyses were performed using a Chrom- pack CP 9000 gas chromatograph (Apeldoorn, the Netherlands) with an FID detector using splitless in- jection. A WCOT Fused Silica, stationary phase: CP-SIL-8 CB $(25 \mathrm{~m} \times 0.25 \mathrm{~mm}$ i.d. with $0.4-$ $\mu \mathrm{m}$ film thick- ness) column was used. Nitrogen was used as carrier

gas and hydrogen and oxygen were used as FID gases. Maestro software was used for data acquisition and processing. Volumes of $1 \mu \mathrm{L}$ were injected using a 10 -

$\mu \mathrm{L}$ microsyringe (Hamilton, IL, USA).

Determination of the organic matter content was

performed with a Tecator ${ }^{\mathrm{TM}}$ Digestion System (Hil- lerod, Denmark) and water content was determined with a Lenton Furnaces oven (London, UK).

The wavenumbers used in the IR scans ranged from 3200 $\mathrm{cm}^{-1}$ to $2700 \mathrm{~cm}^{-1}$, but absorbance was measured at the maximum peak of $2930 \mathrm{~cm}^{-1}$ (sub- tracting the baseline). Calibration curves were con- structed using six standard solutions with concentra- tions ranging from $4.91 \mathrm{mg} \mathrm{L}^{-1}$ to $39.78 \mathrm{mg} \mathrm{L}^{-1}$. To reduce the detection and quantification limits of the GC-FID method, a pre-concentration step was in-cluded in the procedure where $10 \mathrm{~mL}$ of the extract was transferred into a vial and evaporated to dryness with a gentle stream of nitrogen and recovered with $1 \mathrm{~mL}$ of pentane. The temperature of the oven was programmed with an initial temperature of $40{ }^{\circ} \mathrm{C}$ (for $2 \mathrm{~min}$ ) and a temperature rise of 6 ${ }^{\circ} \mathrm{C} \min ^{-1}$ up to $290{ }^{\circ} \mathrm{C}$. Detector and injector temperatures were set at $325{ }^{\circ} \mathrm{C}$ and $285{ }^{\circ} \mathrm{C}$, respectively. Calibration curves for GC-FID were based on measurements of nine standard solutions with concentrations in the range from $500 \mathrm{mg}$ $\mathrm{L}^{-1}$ to $4000 \mathrm{mg} \mathrm{L}^{-1}$.

\section{Samples and their treatment}

In total, fifteen samples were collected (three from five different sites: a farm, road, beach, commercial gas station, and vicinity of Portuguese oil refinery) in the north of Portugal. These groups of three samples were collected in distinct localities sufficiently distant to avoid soil similarities (minimum distance between sampling sites of the same type was $1.2 \mathrm{~km}$ ). The five different types of locations chosen to study aimed at the collection of samples from sites that were presum- ably uncontaminated (farm and beach) and proba- bly contaminated (roads, commercial gas stations, and vicinity of oil refinery). Approximately $1 \mathrm{~kg}$ of a sam- ple was collected at each sampling point from the up- per layer of soil of $0-20 \mathrm{~cm}$ using a spade. All samples were thoroughly mixed to ensure homogeneity and, af- ter airdrying and sieving through a 2-mm sieve, were stored at $4{ }^{\circ} \mathrm{C}$ (USEPA, 1996c).

For the extraction, approximately $3 \mathrm{~g}$ of soil was used and thoroughly mixed with $150 \mathrm{~mL}$ of extrac- tion solvent and extracted over $4 \mathrm{~h}$. The extraction was performed in triplicate in 1,1,2-trichloro-1,2,2- trifluoroethane for IR and pentane for GC-FID analy- ses, respectively (Current \& Tilotta, 1997). After theextraction, $0.3 \mathrm{~g}$ of silica gel was added to adsorb the polar material, such as vegetable oils and animal fats. The USEPA method 8440 (USEPA, 1996c) re-gards all "oil and grease" materials that are not elim- inated by silica gel adsorption as "petroleum hydro- carbons". The extracts were filtered through What- man GF/C filters (UK) using a DINKO D-95 vacuum pump (Barcelona, Spain). Sodium sulphate was added to the sample during the extraction procedure and in the filtration process to eliminate residual water. The extracts thus obtained were analysed by IR and GC- FID. Other procedures are described in the literature that use different solvents, such as tetrachloroethylene (Dumitran et al., 2009) or hexane (Rauckyte et al., 2010), or sonication methods to enhance extraction (Shin \& Kwon, 2000; Miclean et al., 2010).

\section{Recovery studies}

Recovery studies were performed using soils with different physical-chemical properties to verify whe- ther the TPH content could be extracted from several types of soil. Hence, two soils samples, both from the north of Portugal, were collected: soil A (collected on a farm) and soil B (collected on a beach). After a preliminary analysis, it was observed that both soils did not contain detectable amounts of TPH.

These samples were fortified with reference oil and diesel standards for IR and GC-FID analyses, respectively at three levels: (I) $5000 \mathrm{mg} \mathrm{kg}^{-1}$, (II) $1000 \mathrm{mg} \mathrm{kg}^{-1}$, and (III) $500 \mathrm{mg}$ $\mathrm{kg}^{-1}$. Pure 1,1,2-trichloro-1,2,2-trifluoroethane or pentane was added to both soils and samples were allowed to stand for $30 \mathrm{~min}$ before extraction, in order to obtain blanks. For fortification level I, and using IR, an aliquot of the extract (1 $\mathrm{mL}$ ) was transferred into a $10-\mathrm{mL}$ volumetric flask and diluted with 1,1,2- trichloro-1,2,2-trifluoroethane (final TPH concentra- tion of $10 \mathrm{mg} \mathrm{L}^{-1}$ ). Level II and III samples could beanalysed directly, because the final concentration was within the linear range of the calibration curve. For the GC analysis, an aliquot of the extract $(10 \mathrm{~mL})$ was transferred into a vial and evaporated to dryness

with a gentle stream of nitrogen and re-dissolved with $1000 \mu \mathrm{L}$, $200 \mu \mathrm{L}$, and $100 \mu \mathrm{L}$ of pentane for fortifica- tion levels I, II, and III, respectively (final TPH con-centration of $1000 \mathrm{mg}$ $\mathrm{L}^{-1}$ for all fortification levels). A vortex mixer was used for homogenisation. The re- covery was calculated by determining the percentage 
Table 1. Analytical characteristics of analysed soils $(n=3)$

\begin{tabular}{|c|c|c|c|c|c|}
\hline \multirow{2}{*}{\multicolumn{2}{|c|}{$\begin{array}{c}\text { Sample } \\
\text { Sampling site }\end{array}$}} & \multicolumn{4}{|c|}{ Sample characteristics $\left( \pm \mathrm{RSD}^{a}\right)$} \\
\hline & & $\begin{array}{l}\text { Density } \\
\mathrm{g} \mathrm{mL}^{-1}\end{array}$ & $\mathrm{pH}$ & $\begin{array}{c}\text { Water content } \\
\%\end{array}$ & $\begin{array}{l}\begin{array}{l}\text { Organic matter } \\
\text { content }\end{array} \\
\end{array}$ \\
\hline $\begin{array}{l}1 \\
2 \\
3 \\
\end{array}$ & Farm (soil A) & $\begin{array}{l}0.7 \pm 2.3 \\
0.7 \pm 2.9 \\
0.6 \pm 2.5\end{array}$ & $\begin{array}{l}7.2 \pm 1.5 \\
7.5 \pm 1.4 \\
7.5 \pm 1.6\end{array}$ & $\begin{array}{l}15.6 \pm 0.7 \\
12.2 \pm 1.5 \\
16.8 \pm 0.5\end{array}$ & $\begin{array}{l}8.6 \pm 1.1 \\
8.2 \pm 1.9 \\
8.5 \pm 0.9 \\
\end{array}$ \\
\hline $\begin{array}{l}4 \\
5 \\
6\end{array}$ & Beach (soil B) & $\begin{array}{l}1.1 \pm 3.3 \\
1.2 \pm 2.7 \\
1.6 \pm 1.1\end{array}$ & $\begin{array}{l}7.3 \pm 0.6 \\
7.6 \pm 0.9 \\
7.6 \pm 1.4\end{array}$ & $\begin{array}{l}1.0 \pm 3.0 \\
0.9 \pm 4.8 \\
0.1 \pm 3.2\end{array}$ & $\begin{array}{l}1.1 \pm 1.1 \\
0.9 \pm 2.1 \\
1.3 \pm 2.8\end{array}$ \\
\hline $\begin{array}{l}7 \\
8 \\
9\end{array}$ & Road & $\begin{array}{l}1.6 \pm 1.9 \\
1.2 \pm 1.5 \\
1.6 \pm 1.0\end{array}$ & $\begin{array}{l}7.8 \pm 1.1 \\
7.1 \pm 1.8 \\
7.4 \pm 1.1\end{array}$ & $\begin{array}{l}0.1 \pm 4.6 \\
1.0 \pm 3.1 \\
0.0 \pm 3.5\end{array}$ & $\begin{array}{l}1.0 \pm 1.6 \\
1.0 \pm 3.3 \\
1.1 \pm 0.9\end{array}$ \\
\hline $\begin{array}{l}10 \\
11 \\
12\end{array}$ & Gas stations & $\begin{array}{l}1.0 \pm 1.2 \\
1.2 \pm 3.9 \\
1.0 \pm 2.1\end{array}$ & $\begin{array}{l}7.2 \pm 1.6 \\
7.8 \pm 2.3 \\
7.6 \pm 1.0\end{array}$ & $\begin{array}{l}2.4 \pm 3.2 \\
1.3 \pm 2.4 \\
2.1 \pm 2.7\end{array}$ & $\begin{array}{l}3.3 \pm 2.8 \\
4.0 \pm 2.8 \\
3.1 \pm 2.4\end{array}$ \\
\hline $\begin{array}{l}13 \\
14 \\
15\end{array}$ & Vicinity of oil refinery & $\begin{array}{l}0.8 \pm 1.1 \\
0.8 \pm 1.6 \\
1.4 \pm 2.4\end{array}$ & $\begin{array}{l}7.0 \pm 1.2 \\
6.6 \pm 1.7 \\
6.8 \pm 1.0\end{array}$ & $\begin{array}{l}3.7 \pm 1.7 \\
3.0 \pm 2.0 \\
0.2 \pm 2.4\end{array}$ & $\begin{array}{l}3.0 \pm 2.5 \\
3.1 \pm 1.8 \\
2.1 \pm 2.7\end{array}$ \\
\hline
\end{tabular}

a) Relative standard deviation.

of the amount of TPH added to the soil, quantified in the soil by both analytical methods.

The matrix effect was also evaluated analysing the equations of the calibration curves obtained us- ing TPH standards prepared in solvent and in extract

solutions of soil A and B.

\section{Results anddiscussion}

\section{Samples characterisation}

Macro parameters ( $\mathrm{pH}$, density, water and organic matter content) for the fifteen soil samples were de-

termined (Hesse, 1972) and are shown in Table 1.

\section{Interferences}

An IR analysis is always susceptible to interfer- ences, so the results should be interpreted accordingly. If the organic matter is not fully removed in the silica gel clean-up, its presence may cause a positive error in the analysis. In soil A (high organic matter content) a strong absorbance was observed between $2700 \mathrm{~cm}^{-1}$ and $3000 \mathrm{~cm}^{-1}$, in contrast to soil B (low organic mat- ter content) where no absorbance was found (Fig.

1a). These interferences were not observed in the GC- FID analysis using soil A or soil B. Matrix effects were originally discussed by Tang and Kerbale (1993) and can lead to a significant increase or decrease in the response of an analyte in a sample compared with a pure standard solution. Matrix effects are attributed to interfering substances which co-extract with the an- alyte of interest and can be a cause of significant error
Table 2. Calibration data and assessment of matrix effect

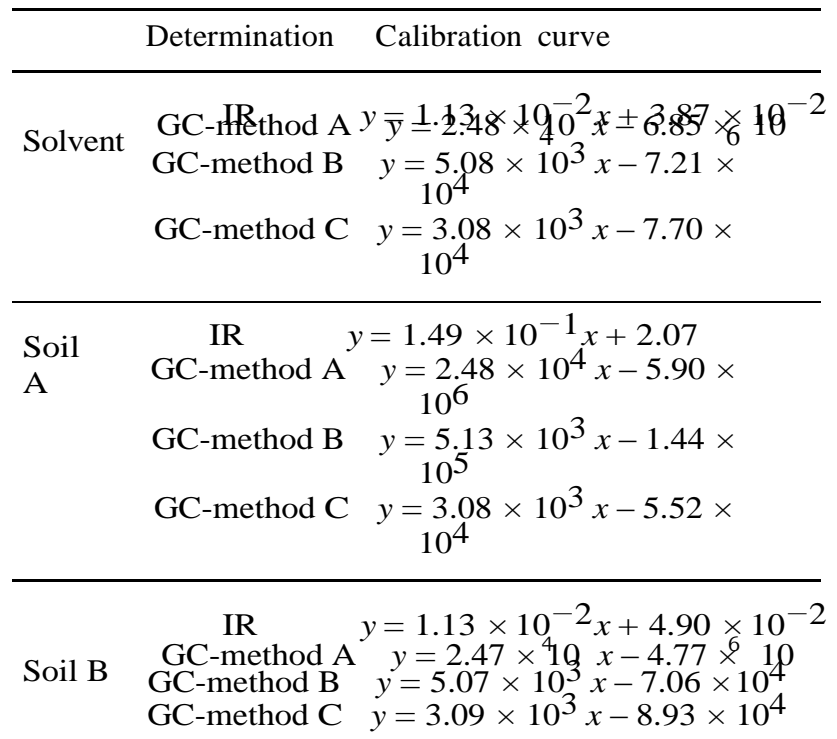

in the accuracy and precision of a method. Therefore, the evaluation of matrix effects is required as a part of quantitative method development (Annesley, 2003). Standard addition can be applied to several analytical methods and is used instead of the calibration curve to resolve the matrix effect (Harris, 2003). The stan- dard addition method was used to determine TPH in all soil samples using IR or GC-FID. The results of the calibration curves (in solvent and in soil A and B extracts) are presented in Table 2 .

From the similar slopes obtained in the GC-FID analyses, independently of the integration method used, it may be concluded that the soil matrix does not have an observable effect on the TPH analysis. On the 
a

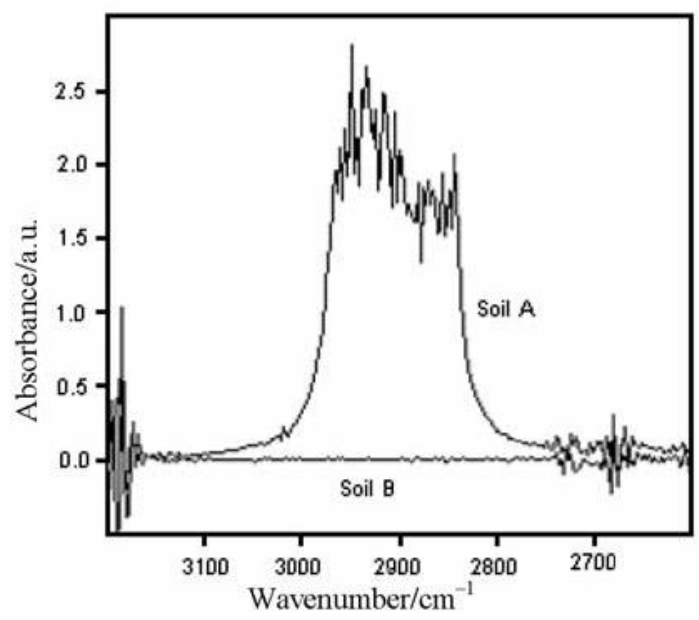

b

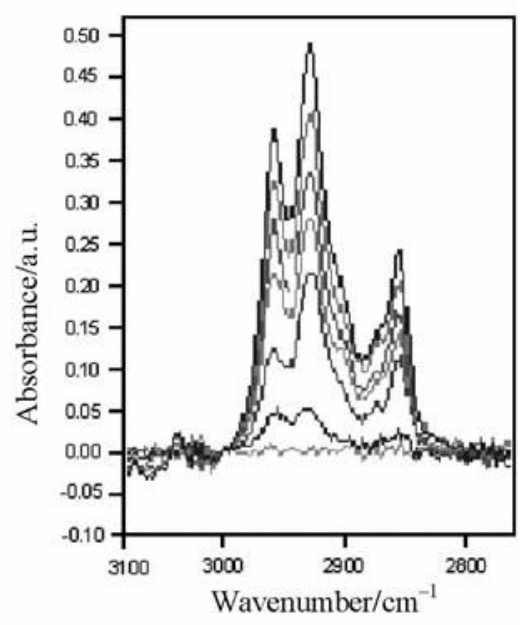

c

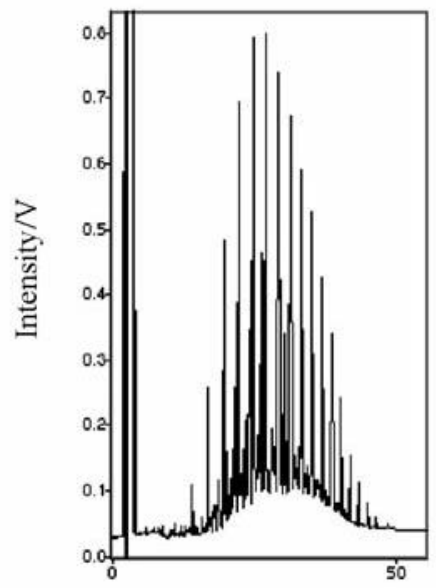

Time/min

Fig. 1. Overlapped IR spectra of soil samples A and B (a), overlapped IR spectra of soil B and standard additions (concentrations of $4.91 \mathrm{mg} \mathrm{L}^{-1}, 16.20 \mathrm{mg} \mathrm{L}^{-1}, 21.25 \mathrm{mg} \mathrm{L}^{-1}, 27.49 \mathrm{mg} \mathrm{L}^{-1}, 33.84 \mathrm{mg} \mathrm{L}^{-1}$, and $39.78 \mathrm{mg}$ $\mathrm{L}^{-1}$ ) (b), GC-FID chromatogram of standard solution (4000 $\left.\mathrm{mg} \mathrm{L}^{-1}\right)$ in soil B (c).

other hand, a significant matrix effect was observed in soil A using IR method, resulting in the higher slope of the respective calibration curve. These results for soils with lower and higher organic matter justify the use of the standard addition method for all the samples analysed in order to reduce the matrix effects.

\section{Linearity, detection, and quantification limits of infrared and chromatographic methods}

Fig. 1b shows the spectra obtained in the analysis of the six standard solutions ranging from $4.91 \mathrm{mg} \mathrm{L}^{-1}$ to $39.78 \mathrm{mg} \mathrm{L}^{-1}$. A linear response was obtained with a correlation coefficient of 0.9999. Under these condi- tions, the detection (LOD) and quantification limits(LOQ) were $2.62 \mathrm{mg} \mathrm{kg}^{-1}$ (mg of TPH per $\mathrm{kg}$ of soil) and $8.73 \mathrm{mg} \mathrm{kg}^{-1}$, respectively. LOD and LOQ werecalculated by multiplying the standard deviations of the obtained linear regressions by 3 and 10, respec- tively, and dividing both by the slope of the respective linear regression equation, as described in Miller and Miller (2000). These results show that IR can be used for monitoring purposes.

A typical GC-FID chromatogram of a standard so- lution is shown in Fig. 1c. Integration of the peaks of the chromatograms was performed using three differ- ent methods (Fig. 2). In method A, denoted as "base-line to baseline", the area considered represents the entire area of the chromatogram within the reten- tion time-range for the fuel type, including the unre- solved complex mixture. For the concentration range from $500 \mathrm{mg} \mathrm{L}^{-1}$ to $4000 \mathrm{mg} \mathrm{L}^{-1}$ (Fig. 2a), a lin- ear response was obtained with a correlation coeffi- cient of 0.9999 . The total area was integrated from

$14.1 \mathrm{~min}$ to $51.0 \mathrm{~min}$ (referring to decane and octa- cosane peaks, respectively). The LOD and LOQ were 
a

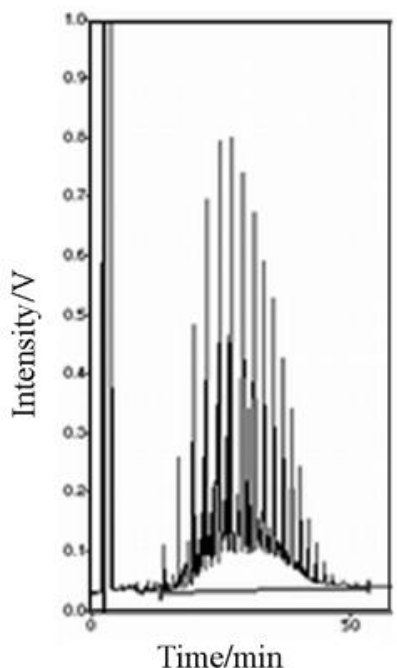

b

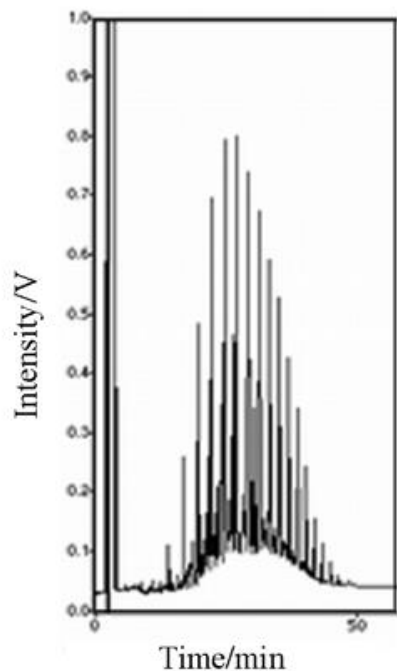

$\mathrm{C}$

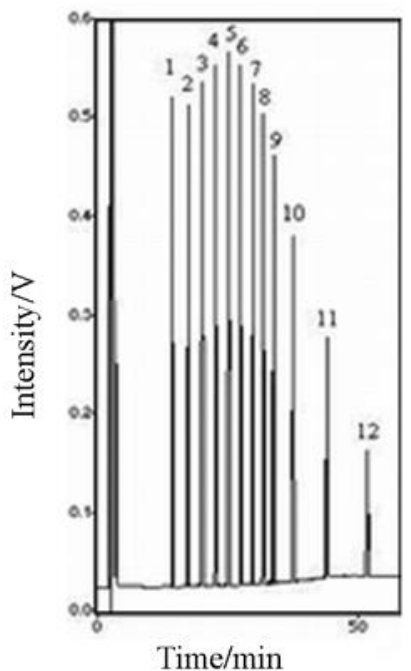

Fig. 2. GC-FID integration methods: "baseline to baseline" (a), "peak to peak" (b), and addition of ASTM standard solution (c). ASTM standard solution components: decane (1), undecane (2), dodecane (3), tridecane (4), tetradecane (5), pentadecane

(6), hexadecane (7), heptadecane (8), octadecane (9), eicosane (10), tetracosane (11), and octacosane (12).

Table 3. TPHs recoveries (mean \pm relative standard deviation, $n=3$ ) from homogenised soil sample type A and $\mathrm{B}$, at three fortification levels (I, II, and III)

Recovery/\% ( \pm RSD)

\begin{tabular}{|c|c|c|c|c|c|c|}
\hline \multirow{3}{*}{ method Soil } & \multirow{2}{*}{\multicolumn{2}{|c|}{ Fortification level }} & & & & \\
\hline & & & & \multicolumn{3}{|c|}{ GC-FID integration } \\
\hline & \multicolumn{2}{|c|}{$\mathrm{mg}_{-1}$} & & A & B & $\mathrm{C}$ \\
\hline \multirow{3}{*}{ A } & I & 5000 & $96 \pm 1$ & $98 \pm 2$ & $99 \pm 2$ & $98 \pm 1$ \\
\hline & II & 1000 & $95 \pm 1$ & $\begin{array}{l}90 \pm 2 \\
98 \pm 2\end{array}$ & $98 \pm 1$ & $\begin{array}{l}90 \pm 1 \\
98 \pm 1\end{array}$ \\
\hline & III & 500 & $94 \pm 3$ & $98 \pm 2$ & $98 \pm 1$ & $98 \pm 2$ \\
\hline \multirow{3}{*}{ B } & I & 5000 & $98 \pm 1$ & $98 \pm 2$ & $98 \pm 2$ & $98 \pm 2$ \\
\hline & II & 1000 & $98 \pm 2$ & $98 \pm 2$ & $98 \pm 2$ & $98 \pm 3$ \\
\hline & III & 500 & $98 \pm 2$ & $98 \pm 1$ & $97 \pm 2$ & $98 \pm 2$ \\
\hline
\end{tabular}

$127.07 \mathrm{mg} \mathrm{kg}^{-1}$ and $423.57 \mathrm{mg} \mathrm{kg}^{-1}$, respectively. Us- ing method B, denoted as "peak to peak", only the twenty-seven most representative peaks in the chro- matograms (Fig. 2b) were considered and integrated. In the range from $500 \mathrm{mg} \mathrm{L}^{-1}$ to $4000 \mathrm{mg} \mathrm{L}^{-1}$, a linear response with a correlation coefficient of 0.9999 was obtained. The LOD and LOQ were $96.16 \mathrm{mg} \mathrm{kg}^{-1}$ and $320.52 \mathrm{mg} \mathrm{kg}^{-1}$, respectively. The last integrated peak had a retention time of $51.0 \mathrm{~min}$. Finally, in method $\mathrm{C}$, the integration considered the retention times of the compounds included in the ASTM D5307 Crude oil quantitative STD analytical standard. Us- ing the same conditions, an ASTM D5307 Crude oil quantitative analytical standard with a concentration of $960 \mathrm{mg} \mathrm{L}^{-1}$ was injected. The mixture consisted of sixteen hydrocarbons, all of 6.25 mass \%. The ASTM standard solution was injected in order to ob- tain the retention times for each hydrocarbon; then, diesel standard solutions (concentration range from
$500 \mathrm{mg} \mathrm{L}^{-1}$ to $4000 \mathrm{mg} \mathrm{L}^{-1}$ ) were injected and twelve peaks with the same retention time as the peaks of ASTM D5307 (Fig. 2c) were integrated. The last inte- grated peak had a retention time of $51.0 \mathrm{~min}$. A linear response was obtained with a correlation coefficient of 0.9999 . The LOD and LOQ were $118.54 \mathrm{mg} \mathrm{kg}^{-1}$ and $395.13 \mathrm{mg} \mathrm{kg}^{-1}$, respectively.

Using GC-FID, methods A and B presented the lowest and highest LOD, respectively. IR provided a much lower LOQ than GC-FID but both methods en- abled the quantification of lower amounts of TPH than the established alert and intervention values (Hesse, 1972).

\section{Fortification levels}

The extraction efficiency was consistent across the whole fortification range and for both soils (with dif- ferent organic matter contents). No significant vari- 
Table 4. Certified and measured concentrations of TPH in the ASTM D5307 (ASTM, 1997h) Crude oil quantitative standard $(n=3)$

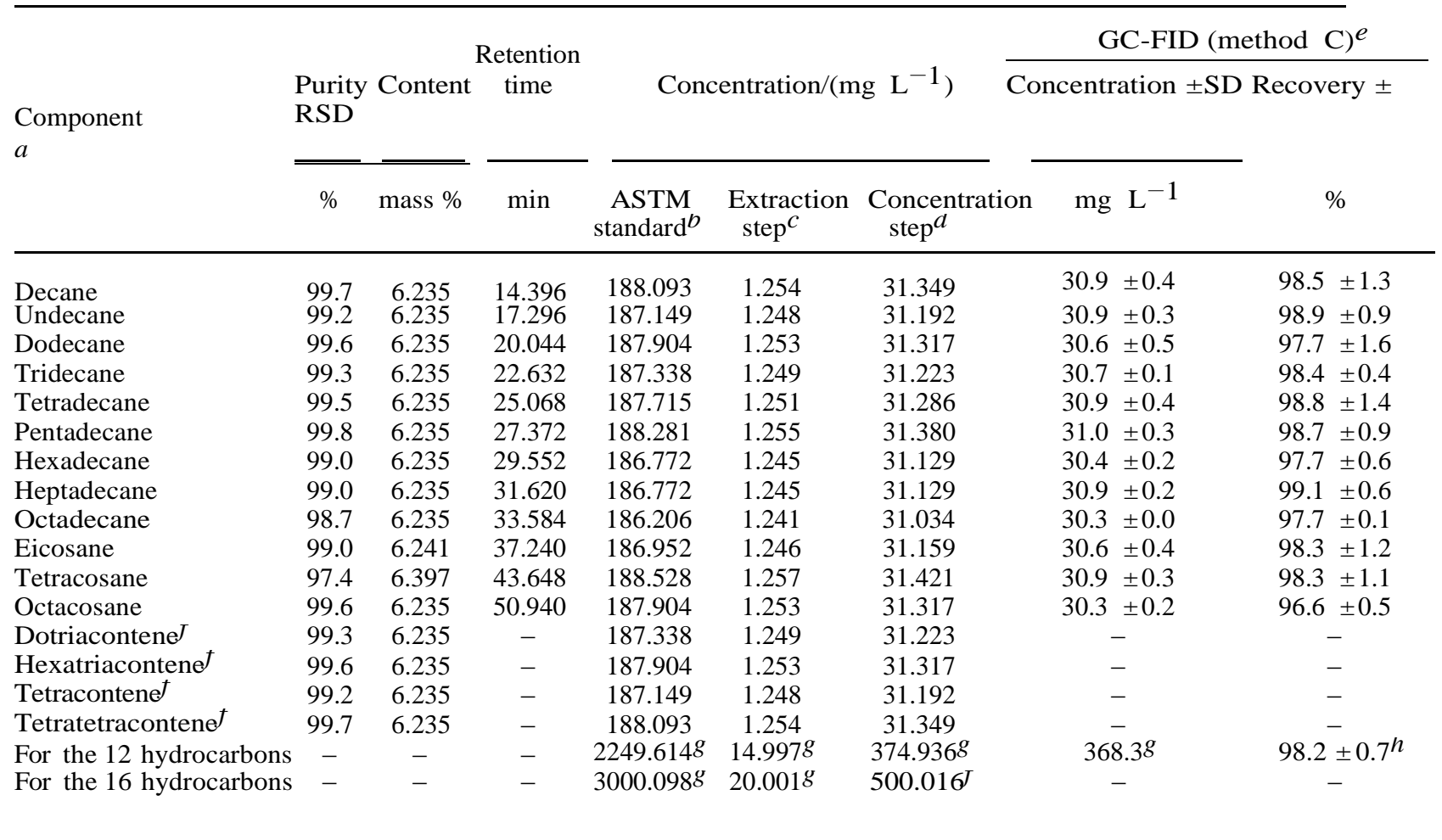

a) See chromatogram in Fig. 2c; b) certified values, soil type B was contaminated with $1 \mathrm{~mL}$ of $3000 \mathrm{mg}^{-1}$ ASTM standard solution; $c$ ) extraction of ASTM standard from $3 \mathrm{~g}$ of contaminated soil type B using $150 \mathrm{~mL}$ of pentane; $d$ ) value after pre- concentration ( $10 \mathrm{~mL}$ of the extract was evaporated with nitrogen and re-dissolved in $400 \mu \mathrm{L}$ of pentane); $e$ ) values estimated experimentally; $f$ ) the last integrated peak was with retention time of 50.94 min; peaks not considered; $g$ ) total concentration measured for the twelve peaks; $h$ ) mean value for the twelve peaks.

ation in the results (Table 3) was observed and the recovery did not differ substantially at the lowest and the highest concentrations for the two types of soils. Three fortification levels were chosen in order to test the recovery values over a certain concentration range.

\section{Analysis of ASTM D5307 Crude oil quantita- tive STD analytical standard}

Validation of the extraction procedure for determination of TPH in soil samples was carried out by analysing a certified reference material. Standard ASTM D5307 solution (3000 $\mathrm{mg} \mathrm{L}^{-1}$ ) was prepared in $1,1,2$ trichloro-1,2,2-trifluoroethane and in pentane. Soil sample B (3 g) was contaminated with $1 \mathrm{~mL}$ of the standard ASTM solution and allowed to stand for $30 \mathrm{~min}$ before extraction. Using IR, determina- tion of the concentration and recovery of individ- ual hydrocarbons was not possible. The absorbance was measured and the concentration obtained was $(19.6 \pm 0.2) \mathrm{mg} \mathrm{L}^{-1}(n=3)$ with the recovery of $97.8 \%(\mathrm{RSD}=0.86 \%, n=3)$. Using GCFID, it

was possible to calculate the concentration and re- covery of each hydrocarbon present in the certified reference material. A pre-concentration step had to be performed (twenty-five times). Concentration and recoveries for each hydrocarbon are presented in Ta- ble 4.
The ASTM standard was successfully extracted from the soil sample with good recoveries in IR and GC-FID analyses. Referring to the similar slopes of the calibration curves obtained with soils $\mathrm{A}$ and $\mathrm{B}$, the values of which are presented in Table 2, it can be deduced that if soil A were used, similar recover- ies could have been achieved within the range of TPH concentrations studied.

\section{Source of spilled oil}

Each crude oil or petroleum product has its unique chemical "fingerprint", providing a basis for identify- ing the source(s) of the spilled oil. Method 8440 cannot be applied to the analysis of petrol and other volatile petroleum fractions, because these fractions evapo- rate during sample preparation (USEPA, 1996c). Toidentify the specific fuel present in the soil samples analysed: a) diesel (1000 $\left.\mathrm{mg} \mathrm{L}^{-1}\right)$ and b) petrol (1000 $\mathrm{mg} \mathrm{L}^{-1}$ ) fuels were injected into a chromato- graph with FID. The fuel chromatograms are pre- sented in Fig. 3.

The chromatograms obtained for both samples are very specific and enabled the identification of the fuel in a specific sample. Therefore, all soil samples were analysed first by GCFID and only the samples con-taminated with diesel fuel were analysed by IR. 
a

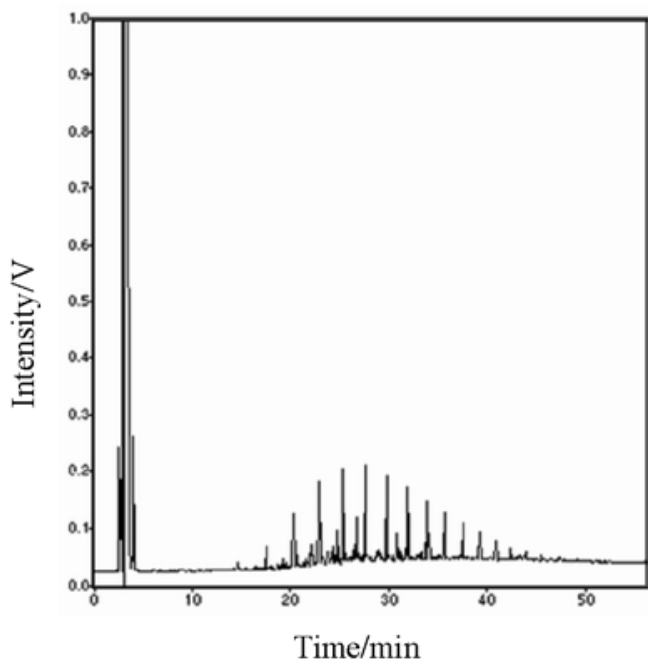

b

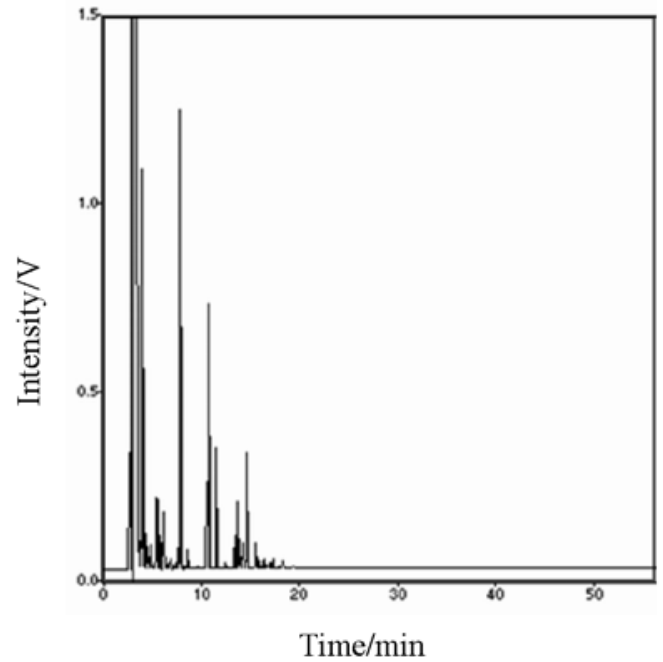

Fig. 3. GC-FID chromatograms of $1000 \mathrm{mg} \mathrm{L}^{-1}$ diesel (a) and $1000 \mathrm{mg} \mathrm{L}^{-1}$ petrol (b) fuels.

Table 5. Concentration of TPH in samples analysed $(n=3)$

\begin{tabular}{|c|c|c|c|c|}
\hline \multirow{3}{*}{$\begin{array}{l}\text { Sampling } \\
\text { site }\end{array}$} & \multicolumn{4}{|c|}{$\mathrm{TPH}$ concentration/ $\left(\mathrm{mg} \mathrm{kg}^{-1}\right)\left( \pm \mathrm{SD}^{a}\right)$} \\
\hline & \multirow{2}{*}{ IR } & \multicolumn{3}{|c|}{ GC-FID integration } \\
\hline & & method A & method B & method C \\
\hline Farm (soil A) & $\begin{array}{l}\text { n.d. } \\
\text { n.d. } \\
\text { n.d. }\end{array}$ & $\begin{array}{l}\text { n.d. } \\
\text { n.d. } \\
\text { n.d. }\end{array}$ & $\begin{array}{l}\text { n.d. } \\
\text { n.d. } \\
\text { n.d. }\end{array}$ & $\begin{array}{l}\text { n.d. } \\
\text { n.d. } \\
\text { n.d. }\end{array}$ \\
\hline Beach (soil B) & $\begin{array}{l}\text { n.d. } \\
\text { n.d. } \\
\text { n.d. }\end{array}$ & $\begin{array}{l}\text { n.d. } \\
\text { n.d. } \\
\text { n.d. }\end{array}$ & $\begin{array}{l}\text { n.d. } \\
\text { n.d. } \\
\text { n.d. }\end{array}$ & $\begin{array}{l}\text { n.d. } \\
\text { n.d. } \\
\text { n.d. }\end{array}$ \\
\hline Road & $\begin{array}{l}45 \pm 2^{b} \\
64 \pm 2^{b} \\
\operatorname{LOQ}^{c} 55 \pm 4^{b} \\
\operatorname{LOQ}^{c}\end{array}$ & $\begin{array}{l}<\mathrm{LOQ}^{c} \\
<\mathrm{LOQ}^{c} \\
<\mathrm{LOQ}^{c}\end{array}$ & $\begin{array}{l}<\mathrm{LOQ}^{c} \\
<\mathrm{LOQ}^{c} \\
<\mathrm{LOQ}^{c}\end{array}$ & $\begin{array}{l}<\mathrm{LOQ}^{c} \\
< \\
<\end{array}$ \\
\hline Gas stations & $\begin{array}{l}532 \pm 25^{d} \\
649 \pm 20^{d} \\
620 \pm 21^{d}\end{array}$ & $\begin{array}{l}561 \pm 13 \\
640 \pm 11 \\
650 \pm 19\end{array}$ & $\begin{array}{l}561 \pm 30 \\
628 \pm 34 \\
632 \pm 19\end{array}$ & $\begin{array}{l}567 \pm 37 \\
639 \pm 10 \\
608 \pm 21\end{array}$ \\
\hline Refinery neighbourhood & $\begin{array}{l}8640 \pm 149^{e} \\
8029 \pm 183^{e} \\
3423 \pm 213^{e}\end{array}$ & $\begin{array}{l}8875 \pm 152 f \\
8326 \pm 239 f \\
3525 \pm 309 f\end{array}$ & $\begin{array}{l}8840 \pm 209 f \\
7973 \pm 255^{f} \\
3505 \pm 225 f\end{array}$ & $\begin{array}{l}9230 \pm 322 f \\
8235 \pm 291^{f} \\
3495 \pm 253^{f}\end{array}$ \\
\hline
\end{tabular}

a) SD - standard deviation; $b$ ) two times sample dilution $(25 \mathrm{~mL}$ of extract in a $50 \mathrm{~mL}$ volumetric flask diluted with $1,1,2$ trichloro- 1,2,2-trifluoroethane to the volume); $c$ ) fifty times sample pre-concentration (10 $\mathrm{mL}$ of extract evaporated to dryness with nitrogen and re-dissolved with $200 \mu \mathrm{L}$ of pentane); $d$ ) twenty-five times sample dilution ( $2 \mathrm{~mL}$ of extract in a $50 \mathrm{~mL}$ volumetric flask diluted with 1,1,2-trichloro-1,2,2-trifluoroethane to the volume); e) two hundred and fifty times sample dilution $(200 \mu \mathrm{L}$ of extract in a $50 \mathrm{~mL}$ volumetric flask diluted with 1,1,2-trichloro-1,2,2-trifluoroethane to the volume); $f$ ) five times sample dilution ( $1 \mathrm{~mL}$ of extract in a $5 \mathrm{~mL}$ volumetric flask diluted with pentane to the volume).

\section{Application to soil samples}

collected near to a road

The results obtained for each soil sample are pre- sented in Table 5. IR and GC-FID determinations (in-tegration methods A, B, and C) showed similar re- sults. As an example, Fig. 4 presents the spectrum ob- tained by IR analysis of a soil 
(sample 9) and a chromatogram obtained by GC-FID analysis of a soil collected in the vicinity of a refinery (sample 14).

In accordance with Dutch legislation (VROM, 1987), there are three limit values of TPH mass per mass of soil: reference ( $\mathrm{S}, 10 \mathrm{mg} \mathrm{kg}^{-1}$ ), intervention (I, $1000 \mathrm{mg} \mathrm{kg}^{-1}$ ), and alert ( $\mathrm{T}, 505 \mathrm{mg} \mathrm{kg}^{-1}$ ). The $\mathrm{S}$ 

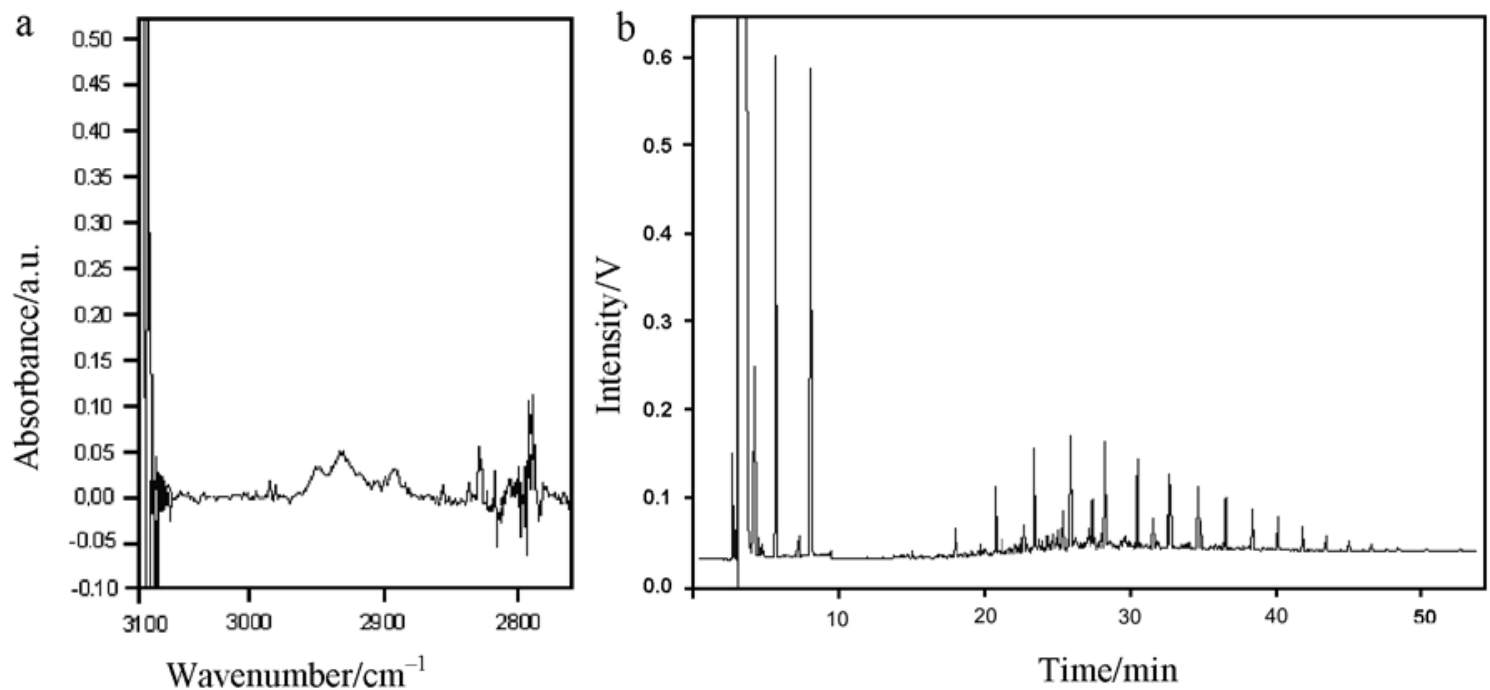

Fig. 4. Representative IR spectrum obtained for soil collected near to a road (sample 9) (a) and GC-FID chromatogram obtainedfor soil collected in the vicinity of an oil refinery (sample 14) (b).

value indicates the level at which the soil and ground- water are considered "clean". The I value indicates the level above which it becomes a risk to human health and to the environment. The higher values (average) in $25 \mathrm{~m}^{3}$ of soil or $100 \mathrm{~m}^{3}$ of groundwater indicate that $\mathrm{T}$ value is the average value between $\mathrm{S}$ and $\mathrm{I}$.

The TPH concentration in the samples from gas stations were higher than the Dutch $\mathrm{T}$ alert value and in the samples collected in the vicinity of a refinery TPH concentrations were above the Dutch I interven- tion value. The results in Table 5 also indicate that the soils collected from a beach and in a farm present no detectable levels of contamination, confirming classifi- cation of presumed uncontaminated soils. The soil collected near to a road showed levels of TPH which did not attain the Dutch alert value, indicating that thesoil, classified as potentially contaminated, was uncon- taminated but required future monitoring. Finally, thesoils collected within gas stations and in the vicinity of an oil refinery confirmed the potentially contaminated status accorded and required remediation action.

\section{Conclusions}

The present work demonstrates that IR and GC- FID can be considered suitable for detection and quan- tification of TPH in soil samples, considering different levels of contamination (ranging from not detectable levels, in soils collected from a farm and a beach, up to $(9230 \pm 322) \mathrm{mg} \mathrm{kg}^{-1}$ in soil collected from the vicin- ity of an oil refinery). However, utilisation of IR is not advisable for soils contaminated with petrol because of the volatilisation losses that occur in the analytical process.

The IR method presents limits of detection and quantification of $3 \mathrm{mg} \mathrm{kg}^{-1}$ and $9 \mathrm{mg} \mathrm{kg}^{-1}$, respec- tively; the gas chromatography method present lim- its of detection and quantification within the ranges of 96 $\mathrm{mg} \mathrm{kg}-1$ to $127 \mathrm{mg} \mathrm{kg}^{-1}$ and $321 \mathrm{mg} \mathrm{kg}^{-1}$ to $424 \mathrm{mg}$ $\mathrm{kg}^{-1}$, respectively, depending on the inte- gration method used. Recovery experiments with soil with high organic matter content using the IR proce- dure provided satisfactory average recovery (around $94 \%$ ) and the respective standard deviation values which were comparable with those obtained by gas chromatography (higher than $97 \%$ ).

The volume of solvent used with the GC-FID method is lower than that used with the IR method, avoiding the use of hazardous solvent (1,1,2-trichloro- 1,2,2-trifluoroethane) and reducing cost per analysis. This volume reduction further decreases waste gen- eration and analyst exposure. There are fewer inter- ferences resulting from organic matter content in the GC-FID method and the analytical costs are lower than with the IR method, although the GC-FID is more timeconsuming.

Acknowledgements. This work was financially supported by Fundac,ão para a Cie,ncia e a Tecnologia through Grant PEst- C/EQB/LA0006/2011 and through the Project PTDC/ECM/ 68056/2006. The authors express their gratitude to Portuguese refinery, Petrogal, S.A. (Oporto, Portugal).

\section{References}

American Petroleum Institute (API) (1992). Methods for de- termination of petroleum hydrocarbons in soil. Washington, DC, USA: American Petroleum Institute. American Petroleum Institute (API) (1994). Interlaboratory study of three methods for analyzing petroleum hydrocarbons in soils (API Publication Number 4599). Washington, DC, USA: American Petroleum Institute.

American Society for Testing and Materials (ASTM) (1997a). Comparison of waterborne petroleum oils by infrared spec- troscopy (D3414). In Annual book of ASTM standards. Philadelphia, PA, USA: American Society for Testing and Materials. 
American Society for Testing and Materials (ASTM) (1997b). Oil and grease and petroleum hydrocarbons in water (D3921). In Annual book of ASTM standards. Philadelphia, PA, USA: American Society for Testing and Materials.

American Society for Testing and Materials (ASTM) (1997c). Comparison of waterborne petroleum oils by fluorescence analysis (D3650). In Annual book of ASTM standards. Philadelphia, PA, USA: American Society for Testing and Materials.

American Society for Testing and Materials (ASTM) (1997d). Determination of the aromatic content and polynuclear aro- matic content of diesel fuels and aviation turbine fuels by su- percritical fluid chromatography (D5186-96). In Annual book of ASTM standards. Philadelphia, PA, USA: American So- ciety for Testing and Materials.

American Society for Testing and Materials (ASTM) (1997e). Oil spill identification by gas chromatography and posi- tive ion electron impact low resolution mass spectrometry (D5739-95). In Annual book of ASTM standards. Philadel- phia, PA, USA: American Society for Testing and Materials. American Society for Testing and Materials (ASTM) (1997f). Comparison of waterborne petroleum oils by gas chromatog- raphy (D3328-90). In Annual book of ASTM standards.

Philadelphia, PA, USA: American Society for Testing and Materials.

American Society for Testing and Materials (ASTM) $(1997 \mathrm{~g})$. Comparison of waterborne petroleum oils by high perfor- mance liquid chromatography (D5037-90). In Annual book of ASTM standards. Philadelphia, PA, USA: American So- ciety for Testing and Materials.

American Society for Testing and Materials (ASTM) (1997h). Determination of boiling range distribution of crude petro- leum by gas chromatography D5307-97. In Annual book of ASTM standards. Philadelphia, PA, USA: American Society for Testing and Materials.

Annesley, T. M. (2003). Ion suppression in mass spectrometry. Clinical Chemistry, 49, 1041-1044. DOI:

10.1373/49.7.1041. Burns, K. A. (1993). Analytical methods used in oil spill studies. Marine Pollution Bulletin, 26, 68-72. DOI: $10.1016 / 0025-$ 326x(93)90093-y.

Current, R. W., \& Tilotta, D. C. (1997). Determination of total petroleum hydrocarbons in soil by on-line supercriti- cal fluid extraction-infrared spectroscopy using a fiber optic transmission cell and a simple filter spectrometer. Journal of Chromatography A, 785, 269277. DOI: 10.1016/s0021- 9673(97)00466-4.

Daling, P. S., Faksness, L. G., Hansen, A. B., \& Stout, S. A. (2002). Improved and standardized methodology for oil spill fingerprinting. Environmental Forensics, 3, 263-278. DOI: 10.1080/713848389.

Dumitran, C., Ion, O., \& Florinel, D. (2009). Spectroscopy and gas chromatographic measurements of TPH in soil samples contaminated with crude oil. Revista de Chimie, 60, 1335-1337.

Eide, I., \& Zahlsen, K. (2005). A novel method for chemical fin-gerprinting of oil and petroleum products based on electro- spray mass spectrometry and chemometrics. Energy \& Fuels, 19, 964-967. DOI: 10.1021/ef049743m.

Ge, Z. F., Brown, C. W., \& Alberts, J. J. (1995). Infrared fiber optic sensor for petroleum. Environmental Science \& Tech- nology, 29, 878-882. DOI:
$10.1021 / \mathrm{es} 00004 \mathrm{a} 007$

Harris, D. C. (2003). Quantitative chemical analysis (6th

ed.).

New York, NY, USA: Freeman.

Hesse, P. R. (1972). A textbook of soil chemical analysis. New York, NY, USA: Chemical Publishing Co.

Krahn, M. M., \& Stein, J. E. (1998). Peer reviewed: Assess- ing exposure of marine biota and habitats to petroleum 
compounds. Analytical Chemistry, 70, 186A-192A. DOI: $10.1021 / \mathrm{ac} 981748 \mathrm{r}$

Krahn, M. M., Ylitalo, G. M., Buzitis, J., Chan, S. L., \& Varanasi, U. (1993). Rapid high-performance liquid chro- matographic methods that screen for aromatic compounds in environmental samples. Journal of Chromatography A, 642, 15-32. DOI: 10.1016/0021-9673(93)80073-h.

Lambert, P., Fingas, M., \& Goldthorp, M. (2001). An eval- uation of field total petroleum hydrocarbon (TPH) sys- tems. Journal of Hazardous Materials, 83, 65-81. DOI: 10.1016/s0304-3894(00)00328-9.

Lynn, T. B., Lynn, A. C., \& Balog, D. (2002). Analysis of SITE program TPH field trial data for SW-846 method 9074 - The PetroFLAG hydrocarbon analyzer. In Proceedings of the 10th International On-Site 2002 Conference, January 22-25, 2002. San Diego, CA, USA.

Mao, D., Lookman, R., Van De Weghe, H., Weltens, R., Van- ermen, G., De Brucker, N., \& Diels, L. (2009). Estimation of ecotoxicity of petroleum hydrocarbon mixtures in soil based on HPLC-GCXGC analysis. Chemosphere, 77, 1508-1513. DOI: 10.1016/j.chemosphere.2009.10.004.

Miclean, M., Levei, E., Gog, A., Ferenczi, L., Majdik, C., Puia, C., \& Roman, C. (2010). Determination of total petroleum hydrocarbons in contaminated soil by FTIR and GC-FID methods. Studia Universitatis Babes-Bolyai, Chemia, 55(3), 8391.

Miller, J. C. \& Miller, J. N. (2000). Statistics for analytical chemistry (3rd ed.). Harlow, UK: Pearson Education.

Ministry of Housing, Physical Planning and Environment (VROM) (1987). Soil protection act. Den Haag, The Nether- lands.

Pál, R., Juhász, M., \& Stumpf, Á. (1998). Detailed analysis of hydrocarbon groups in diesel range petroleum fractions with on-line coupled supercritical fluid chromatography-gas chromatography-mass spectrometry. Journal of Chromatog- raphy A, 819, 249257. DOI: 10.1016/s0021-9673(98)00505-6.

Park, I. S., \& Park, J. W. (2011). Determination of a risk man- agement primer at petroleum-contaminated sites: Developing new human health risk assessment strategy. Journal of Haz- ardous Materials, 185, 1374 1380. DOI:10.1016/j.jhazmat. 2010.10.058

Rauckyte, T., Zak, S., Pawlak, Z., \& Oloyede, A. (2010). De- termination of oil and grease, total petroleum hydrocarbons and volatile aromatic compounds in soil and sediment sam- ples. Journal of Environmental Engineering and Landscape Management, 18(3), 163-169. DOI: 10.3846/jeelm.2010.19.

Schreier, C. G., Walker, W. J., Burns, J., \& Wilkenfeld, R. (1999). Total organic carbon as a screening method for petroleum hydrocarbons. Chemosphere, 39, 503-510. DOI: 10.1016/s00456535(98)00598-0.

Shin, H. S., \& Kwon, O. S. (2000). The simultaneous analy- sis of benzene, toluene, ethylbenzene, $o, m, p$ xylenes and total petroleum hydrocarbons in soil by GC-FID after ultra- sonication. Bulletin of Korean Chemical Society, 21, 1101-1105.

Sink, C. W., \& Hardy, D. R. (1994). Quantification of compound classes in complex mixtures and fuels using HPLC with dif- ferential refractive index detection. Analytical Chemistry, 66, 1334-1338. DOI: 10.1021/ac00080a020.
Tang, L., \& Kerbarle, P. (1993). Dependence of ion intensity in electrospray mass spectrometry on the concentration of the analytes in the electrosprayed solution. Analytical Chem- istry, 65, 3654-3668. DOI: 10.1021/ac00072a020.

United States Environmental Protection Agency (USEPA) (1978). Test method for evaluating total recoverable petro- leum hydrocarbons (Spectrophotometric, Infrared) (Method 418.1). Washington, DC, USA: U.S. Government Printing Office. 
United States Environmental Protection Agency (USEPA) (1996a). Turbidimetric screening method for total recover-able petroleum hydrocarbons in soil (Method 9074). Wash- ington, DC, USA: U.S. Government Printing Office.

United States Environmental Protection Agency (USEPA) (1996b). Total petroleum hydrocarbons (TPH) as gasoline and diesel (Method 8015B). Washington, DC, USA: U.S. Government Printing Office.

United States Environmental Protection Agency (USEPA) (1996c). Total recoverable petroleum hydrocarbon by infrared spectrophotometry (Method 8440). Washington, DC, USA:

U.S. Government Printing Office.

United States Environmental Protection Agency (USEPA) (1998). n-Hexane extractable material (HEM) for sludge, sediment, and solid samples (Method 9071B). Washington, DC, USA: U.S. Government Printing Office.

Wang, Z. D., \& Fingas, M. (1997). Developments in the anal- ysis of petroleum hydrocarbons in oils, petroleum prod- ucts and oil-spill-related environmental samples by gas chro- matography. Journal of Chromatography A, 774,51-78. DOI: 10.1016/s0021-9673(97)00270-7.
Wang, Z. D., \& Fingas, M. F. (2003). Development of oil hy- drocarbon fingerprinting and identification techniques. Ma- rine Pollution Bulletin, 47, 423-452. DOI: $10.1016 / \mathrm{s} 0025-326 x(03) 00215-7$.

Wang, Z. D., Fingas, M., \& Page, D. S. (1999). Oil spill identi- fication. Journal of Chromatography A, 843, 369-411. DOI: 10.1016/s0021-9673(99)00120-x.

Wang, S. J., Guo, G. L., Yan, Z. G., Lu, G. L., Wang, Q. H.

\& Li, F. S. (2010). The development of a method for the qualitative and quantitative determination of petroleum hy- drocarbon components using thin-layer chromatography with flame ionization detection. Journal of Chromatography A, 1217, 368-374. DOI: 10.1016/j.chroma.2009.11.022.

Wright, K. A. (1995). Evaluation of a new field test kit for determining total petroleum hydrocarbon concentrations in soil at a site contaminated by diesel fuel. In Proceedings of the AEHS Conference on Hydrocarbon Contaminated Soils, January 11-13, 1995. New Orleans, LA, USA. 